\title{
An intelligent sport shoe to prevent ankle inversion sprain injury
}

\author{
Daniel TP Fong \\ From 3rd Congress of the International Foot and Ankle Biomechanics Community \\ Sydney, Australia. 11-13 April 2012
}

\section{Background}

Ankle sprain injury is common in sports. This study presents an intelligent sport shoe to prevent it.

\section{Materials and methods}

(1) Sensing: Five subjects performed various sporting motions with data collected from a plantar pressure system to reconstruct the ankle supination torque determined from a motion capture system with a force plate. Validation test on another five subjects was conducted. (2) Identification: Six subjects performed simulated subinjury and non-injury trials with the dorsal foot kinematics measured by 8 wearable motion sensors. Data was used to train a support vector machine to establish a mathematics algorithm for identification, which was validated on another 6 subjects, with an expected accuracy of $90 \%$. An uni-axial gyrometer was placed at the position with the best accuracy for identifying ankle sprain hazard, with a threshold suggested from a database of ankle inversion velocity from real injury incidents, sub-injury trials and non-injury motions. (3) Correction: Myoelectric stimulations with different delay time $(0,5,10$ and $15 \mathrm{~ms})$ were delivered to the peroneal muscles of 10 subjects performing unanticipated subinjury trials in a laboratory. The effect was quantified by the heel tilting angle and its velocity as determined by a motion analysis system.

\section{Results}

(1) Sensing: a system with 3 pressure sensors was developed to monitor the ankle supination torque with overall root mean square error as $6.91 \mathrm{Nm}$, which was $6 \%$ of the peak values recorded (Fong et al, 2008a). (2) Identification: A method with one gyrometer at the heel to

Correspondence: dfong@ort.cuhk.edu.hk

Department of Orthopaedics and Traumatology, Faculty of Medicine, The Chinese University of Hong Kong, Hong Kong identify hazardous motion with $91.3 \%$ accuracy was developed (Chu et al, 2010). (3) Correction: significant reduction of the heel tilting angle and velocity from 18 to 9-13 degrees and from 200-250 to $140-170 \mathrm{deg} / \mathrm{s}$ was achieved.

\section{Conclusions}

An intelligent anti-sprain sport shoe with a 3-step intelligent system is successfully invented, and is soon being ready for commercialization.

Published: 10 April 2012

\section{References}

1. Fong DTP, Chan YY, Hong Y, Yung PSH, Fung KY, Chan KM: A threepressure-sensor (3PS) system for monitoring ankle supination torque during sport motions. Journal of Biomechanics 2008, 41:2562-2566.

2. Chu WWS, Fong DTP, Chan YY, Yung PSH, Fung KY, Chan KM: Differentiation of ankle sprain motion and common sporting motion by ankle inversion velocity. Journal of Biomechanics 2010, 43:2035-2038.

doi:10.1186/1757-1146-5-S1-K6

Cite this article as: Fong: An intelligent sport shoe to prevent ankle inversion sprain injury. Journal of Foot and Ankle Research 2012 5(Suppl 1): K6.

Submit your next manuscript to BioMed Central and take full advantage of:

- Convenient online submission

- Thorough peer review

- No space constraints or color figure charges

- Immediate publication on acceptance

- Inclusion in PubMed, CAS, Scopus and Google Scholar

- Research which is freely available for redistribution

Submit your manuscript at www.biomedcentral.com/submit
() Biomed Central
C Biomed Central

(C) 2012 Fong; licensee BioMed Central Ltd. This is an Open Access article distributed under the terms of the Creative Commons Attribution License (http://creativecommons.org/licenses/by/2.0), which permits unrestricted use, distribution, and reproduction in any medium, provided the original work is properly cited. 